\title{
Clear Cell Chondrosarcoma
}

National Cancer Institute

\section{Source}

National Cancer Institute. Clear Cell Chondrosarcoma. NCI Thesaurus. Code C6475.

A rare, usually low grade chondrosarcoma characterized by the presence of tumor cells with clear cytoplasm. It usually arises in the epiphyseal ends of long bones. 